ASIMTOT: JURNAL KEPENDIDIKAN MATEMATIKA

Volume 1 Nomor 1, Januari - Mei 2019, halaman 41 - 49

Tersedia Daring pada https://journal.unwira.ac.id/index.php/Asimtot

\title{
PENGARUH DISPOSISI MATEMATIS TERHADAP KEMAMPUAN PEMECAHAN MASALAH MATEMATIS SISWA
}

\section{THE EFFECT OF MATHEMATICAL DISPOSITION ON STUDENTS MATHEMATICAL PROBLEM ABILITY}

\author{
Gisela Elfira Mayratih, Samuel Igo Leton, Irmina Veronika Uskono \\ Universitas Katolik Widya mandira \\ giselamayratih@yahoo.co.id, letonsamuel@gmail.com, veni_uskono@yahoo.com
}

\begin{abstract}
Abstrak: Penelitian ini bertujuan untuk mengetahui pengaruh disposisi matematis siswa terhadap kemampuan pemecahan masalah matematis siswa pada kelas VII SMP. Jenis penelitian yang digunakan yaitu kuantitatif . Sampel dalam penelitian ini kelas VII A yang berjumlah 30 orang yang dipilih menggunakan simple random sampling dari 6 kelas yang ada. Jenis data dalam penelitan ini yaitu data primer. Setelah data dianalisis diperoleh persamaan regresi sebagai berikut : $Y=16.312+0.523 X$.. Berdasarkan analisis data diperoleh bahwa $\mathrm{Uji}_{\mathrm{t}} \mathrm{hitung}=3.296$ dengan signifikansi $=0.003$ dan $\mathrm{t}_{\text {tabel }}=2.048$. maka $\mathrm{t}_{\text {hitung }}=3.296>2.048=\mathrm{t}_{\text {tabel }}$ artinya data berdistribusi normal. Untuk melihat pencapaian indikator disposisi siswa kelas VIIA SMP dihitung rata-rata dari setiap indikator dan diperoleh rata-rata pencapaian indikator disposisi matematis yaitu $50.08 \%$. Sedangkan untuk pengelompokkan disposisi matematis kemampuan pemecahan masalah diperoleh disposisi tertinggi memiliki rata-rata 63.04, disposisi sedang memiliki rata-rata 43.56, dan disposisi rendah memiliki rata-rata 40.51. Dengan demikian, dapat disimpulkan ada pengaruh disposisi matematis terhadap kemampuan pemecahan masalah matematis siswa kelas VIIA SMP.
\end{abstract}

Kata Kunci: Disposisi Matematis Siswa, Kemampuan Pemecahan Masalah Matematis

\begin{abstract}
This study aims to determine the effect of students' mathematical dispositions on mathematical problem solving abilities of students in class VII of SMP. The type of research used is quantitative. The sample in this study was class VII A, amounting to 30 people who were selected using simple random sampling from 6 existing classes. The type of data in this research is primary data. After the data is analyzed the regression equation is obtained as follows: $Y=16,312+0.523 X$. Based on the data analysis, it was found that the $t$-test $=$ 3.296 with significance $=0.003$ and table $=2.048$. then $t$ count $=3.296>2.048=t$ table means that data is normally distributed. To see the achievement of the disposition indicators of junior high school students in the junior high school class, the average of each indicator is calculated and the achievement of the mathematical disposition indicator is 50.08\%. Whereas for grouping mathematical dispositions, problem solving abilities obtained the highest dispositions having an average of 63.04, moderate dispositions having an average of 43.56, and low dispositions having an average of 40.51. Thus, it can be concluded that there is an influence of mathematical disposition on mathematical problem solving abilities of students of junior high school class.
\end{abstract}

Keywords: Students Mathematical Disposition, Students Mathmematical Problem Solving Abilities

Cara Sitasi: Gisela, E.M.,Samuel I,L. \& Irmina, V,U. (2019). Pengaruh Disposisi Matematis Terhadap Kemampuan Pemecahan Masalah Matematis Siswa. Asimtot: Jurnal Kependidikan Matematika, 1(1), 47 - 55 
Matematika merupakan salah satu pelajaran yang memiliki tujuan menata nalar serta membentuk kepribadian siswa. Tujuan lainnya yaitu siswa dapat memecahkan masalah matematika dan menerapkannya dalam kehidupan. Agar tujuan tersebut dapat dicapai dengan baik, maka siswa diwajibkan memiliki rasa ingin tahu, perhatian, dan minat dalam mempelajari matematika. Siswa juga hendaknya memiliki sikap ulet dan percaya diri dalam pemecahan masalah matematika.

Kebutuhan akan pemahaman dan penggunaan matematika dalam kehidupan sehari - hari maupun di dunia kerja semakin besar dan terus bertambah. Menjawab kebutuhan tersebut, maka pemecahan masalah siswa menjadi fokus dalam pembelajaran matematika (Nasution, 2018).

The National Council of Teacher of Mathematics (1989), menyatakan pemecahan masalah seharusnya menjadi fokus sentral dari kurikulum matematika. Dengan demikian pemecahan masalah menjadi tujuan utama dari semua pembelajaran matematika (Lahinda \& Jailani, 2015).

Pemecahan masalah penting dalam matematika karena dalam proses pembelajaran maupun penyelesaian, siswa dimungkinkan memperoleh pengalaman menggunakan pengetahuan serta keterampilan yang sudah dimiliki untuk diterapkan sebagai pemecahan masalah pada situasi baru.

Oleh karena itu, dalam rangka memecahkan masalah matematika, siswa harus menggali pengetahuan mereka dan melalui proses ini siswa akan lebih terampil dalam pemecahan masalah matematika. Peran guru dalam proses pemecahan masalah yaitu memberikan kesempatan bagi siswa untuk memecahkan masalah. Ketika guru mengetahui proses pemecahan masalah yang dilakukan siswa, maka guru dapat membantu siswa yang mengalami pemecahan masalah.

Faktor utama yang dapat dilihat dalam kemampuan pemecahan masalah matematis siswa yaitu sikap menghargai terhadap pembelajaran matematika. Berdasarkan Pengalaman Praktik Lapangan (PPL) pada tahun ajaran 2017/2018, banyak siswa menganggap pelajaran matematika merupakan pelajaran yang sulit dan menyeramkan sehingga tidak sedikit siswa yang menghindar dari pelajaran tersebut.

Salah satu syarat seorang anak mahir dalam bermatematika adalah memiliki positive disposition, yaitu sikap bahwa matematika sangat bermanfaat dalam kehidupannya. Rendahnya sikap positif siswa terhadap pembelajaran matematika akan berpengaruh terhadap kemampuan pemecahan masalah matematis siswa. Siswa menjadi kurang tertarik dalam memecahkan masalah matematis.

Faktor utama yang menentukan kesuksesan siswa dalam belajar matematika adalah disposisi matematis siswa terhadap matematika (Sumarmo, 2013). Polking menyatakan disposisi terhadap suatu bidang studi menunjukkan (1) rasa percaya diri dalam menggunakan bidang studi yang berdangkutan memecahkan masalah, memberi alasaan dan mengkomunikasikan gagasan, (2) fleksibilitas dalam menyelidiki gagasan dan berusaha mencari metoda alternatif dalam memecahkan masalah, (3) tekun mengerjakan tugas, (4) minat, rasa ingin tahu (curiosity), dan dayatemu dalam melakukan tugas mereka sendiri, (5) menilai aplikasi bidang studi yang bersangkutan ke situasi lain dan pengalaman sehari-hari, (6) apresiasi peran bidang studi yang bersangkutan dalam kultur dan nilai (Sumarmo, 2013). 
Pentingnya sikap disposisi matematis terhadap siswa yaitu umtuk mencapai tujuan pembelajaran matematika yakni memiliki sikap menghargai kegunaan matematika dalam kehidupan, sikap rasa ingin tahu, perhatian dan minat dalam mempelajari matematika, serta sikap ulet dan percaya diri dalam pemecahan masalah matematika. Seseorang yang memiliki disposisi matematis yang tinggi akan membentuk individu yang tangguh, ulet, bertanggung jawab, memiliki motif berprestasi yang tinggi, serta membantu individu mencapai hasil terbaiknya (Sumarmo, 2013).

Disposisi siswa sangat berpengaruh terhadap kemampuan pemecahan masalah matematis siswa. Jika siswa menghargai pelajaran matematika dengan sikap positif, maka kemampuan pemecahan masalah siswa akan dicapai dengan baik. Sikap positif siswa daalam menghargai pelajaran matematika dapat ditunjukkan dengan rasa percaya diri dalam memecahkan masalah matematis, fleksibilitas atau sikap terbuka dengan sesama (saling berbagi dan menerima pendapat), rasa ingin tahu yang tinggi terhadap masalah matematika, dan menyikapi dengan rasa senang/menyukai terhadap matematika. Dengan adanya sikap positif terhadap pelajaran matematika, maka siswa akan menjadi individu yang tangguh, ulet, bertanggung jawab, serta dapat mencapai hasil terbaik dalam pemecahan masalah matematika.

Kondisi ideal yang akan dicapai dalam pembelajaran matematika secara khusus di Indonesia, terdapat dalam tujuan pembelajaran matematika. Adapun tujuan itu yakni (a) Memahami konsep matematika, (b) menggunakan penalaran, (c) kemampuan memecahkan masalah, mengkomunikasikan gagasan dengan simbol, (e) memiliki sikap menghargai kegunaan matematika dalam kehidupan (Lahinda \& Jailani, 2015). Namun kenyataan yang terjadi adalah nilai matematika di Indonesia belum mencapai seperti yang diharapkan Berdasarkan data yang diambil dari Pos Kupang, untuk pelajaran matematika selalu rendah tiap tahunnya.

Tahun 2018 rata - rata nasional matematika di angka 31,38. Tahun 2017 rata - rata nasional matematika di angka 52,69, dan di tahun 2016 rata - rata nilai matematika di angka 61,33. Berdasarkan Pengalaman Praktik Lapangan pada tahun 2018, kelima tujuan pembelajaran matematika belum sepenuhnya tercapai. Buktinya banyak siswa yang tidak mencapai Nilai Kriteria Ketuntasan Maksimal (KKM) dengan nilai 70 saat ujian semester. Dari kelima tujuan yang harus dicapai oleh semua siswa, peneliti akan melakukan penelitian mengenai pengaruh kemampuan pemecahan masalah matematis terhadap disposisi matematis siswa yang perlu diupayakan untuk memperbaiki kualitas pendidikan.

Berdasarkan uraian diatas penulis termotivasi untuk melakukan penelitian dengan judul Pengaruh Disposisi Matematis Terhadap Kemampuan Pemecahan Masalah Matematis Siswa.

\section{Metode Penelitian}

Jenis penelitian ini adalah penelitian kuantitatif menggunakan analisis regresi sederhana.

Penelitian ini dilakukan di kelas VII SMP tahun ajaran 2018/2019. Sampel yang digunakan pada penelitian ini yaitu kelas VIIA. Data penelitian ini yaitu data primer berupa tes untuk mengukur kemampuan pemecahan masalah matematis dan angket 
yang digunakan untuk mengukur disposisi matematis siswa. Angket berjumlah 28 butir, sedangkan tes berupa soal uraian berjumlah 5 nomor soal. Angket diberikan sebelum posttest. Instrumen tes dianalisis melalui tiga langkah pengujian yaitu uji normalitas angket dan uji normalitas posttest, uji linearitas, dan uji regresi linear sederhana.

Teknik analisis data yang digunakan yaitu uji normalitas yang bertujuan untuk mengetahui normalitas data angket dan data posttest. Kemudian dilanjutkan uji linearitas yang bertujuan untuk mengetahui linearnya data angket dan data posttest, selanjutnya pengujian hipotesis menggunakan analisis regresi sederhana untuk mengetahui pengaruh disposisi terhadap kemampuan pemecahan masalah matematis siswa.

\section{Hasil Penelitian dan Pembahasan}

\section{Hasil}

Sebelum dilakukan uji hipotesis, terlebih dahulu dilakukan uji normalitas dan uji linearitas. Uji normalitas digunakan untuk mengetahui apakah data yang digunakan berdistribusi normal atau tidak. Uji normalitas data menggunakan uji Kolmogorv-Smirnov. Kriteria pengujian normalitas dengan taraf kesalahan 5\% yaitu jika jika nilai signifikansinya lebih besar dari 0.05 maka data berdistribusi normal, sedangkan jika nilai signifikansinya lebih kecil dari 0.05 maka data tidak berdistribusi normal.

Tabel 1. Uji normalitas data angket

\begin{tabular}{llll}
\hline $\begin{array}{l}\text { Asymp. } \\
\begin{array}{l}\text { Sig. }(2- \\
\text { tailed })\end{array}\end{array}$ & $\mathrm{D}_{\text {hitung }}$ & $\mathrm{D}_{\text {tabel }}$ & Keterangan \\
\hline 0.200 & 0.094 & 0.242 & $\begin{array}{l}\text { Berdistribusi } \\
\text { normal }\end{array}$ \\
\hline
\end{tabular}

Berdasarkan hasil analisis uji normalitas untuk Variabel $\mathrm{X}$ (Disposisi Matematis) dengan $a=0.05$ pada output SPSS 22.00 diperoleh nilai Asymp. Sig (2tailed $)=0.200>0.05=a$ normal atau $\mathrm{D}_{\text {hitung }}$ $=0.094<0.242=D_{\text {tabel }}$ maka data berdistribusi normal.

Tabel 2. Uji normalitas data soal uraian

\begin{tabular}{cccc}
\hline $\begin{array}{c}\text { Asymp. } \\
\text { Sig. }(2- \\
\text { tailed) }\end{array}$ & $\mathrm{D}_{\text {hitung }}$ & $\mathrm{D}_{\text {tabel }}$ & keterangan \\
\hline 0.200 & 0.074 & 0.242 & $\begin{array}{c}\text { Berdistribusi } \\
\text { normal }\end{array}$ \\
\hline
\end{tabular}

Berdasarkan hasil uji normalitas untuk variabel Y (kemampuan pemecahan masalah matematis)pada output SPSS 22.00 diperoleh nilai Asymp. Sig (2-tailed) $=0.200>0.05=a$ atau $\mathrm{D}_{\text {hitung }}=0.074<0.242=\mathrm{D}_{\text {tabel }}$, maka data berdistribusi normal.

Uji linearitas digunakan untuk mengetahui apakah data yang digunakan memiliki hubungan yang linear atau tidak. Uji linearitas bertujuan untuk mengetahui apakah variabel $\mathrm{X}$ dan variabel $\mathrm{Y}$ mempunyai hubungan yang linear atau tidak pada taraf signifikan 0.05 .

Dengan melihat nilai $\mathrm{F}_{\text {hitung }}$ dengan $\mathrm{F}_{\text {tabel, }}$, pada taraf signifikan $5 \%$, kaidah pengujian linieritas yang digunakan sebagai berikut :

Tabel 3. Uji linearitas data angket dan posttest

\begin{tabular}{|c|c|c|c|c|}
\hline $\begin{array}{l}\text { Hubungan } \\
\text { antara } \\
\text { variabel }\end{array}$ & $\mathrm{F}_{\text {hitung }}$ & $\mathrm{F}_{\text {tabel }}$ & Sig. & keterangan \\
\hline $\begin{array}{l}\text { Variabel } \\
\mathrm{X} \text { dengan } \\
\text { Variabel } \\
\mathrm{Y}\end{array}$ & 0.703 & 4.38 & 0.753 & Linear \\
\hline
\end{tabular}


Berdasarkan tabel 3 hasil analisis uji linieritas variabel $\mathrm{X}$ terhadap $\mathrm{Y}$, dilihat dari nilai signifikansi pada Deviation From Linearity $=0.544>0.05=a$ dan diperoleh nilai $\mathrm{F}_{\text {hitung }}$ yaitu $=0.703$ dengan $a=$ 0.05 , Hasil perhitungan yang diperoleh nilai $\mathrm{F}_{\text {tabel }}=4.38$. karena nilai signifikansi $=0.753$ $>0.05=a$ dan $\mathrm{F}_{\text {hitung }}=0.703<4.38=\mathrm{F}_{\text {tabel }}$ maka terima $\mathrm{H}_{0}$ dan dapat disimpulkan bahwa disposisi matematis (variabel $\mathrm{X}$ ) dan kemampuan pemecahan masalah matematis (variabel Y) terdapat hubungan yang linear.

Persamaan garis regresi sederhana digunakan untuk menyatakan bentuk hubungan variabel bebas $(X)$ dengan variabel terikat $(Y)$. Rumus persamaan regresi sederhana yaitu : $Y=\mathrm{a}+\mathrm{b} X$.

\begin{tabular}{|c|c|c|c|c|c|c|}
\hline \multirow{3}{*}{$\begin{array}{l}\text { Mod } \\
\text { el }\end{array}$} & \multirow[b]{2}{*}{$\begin{array}{l}\text { Cons } \\
\text { tant } \\
16.3\end{array}$} & \multicolumn{2}{|c|}{$\begin{array}{l}\text { Unstandardi } \\
\text { zed } \\
\text { Coefficients }\end{array}$} & \multicolumn{2}{|c|}{$\begin{array}{l}\text { Standardize } \\
\text { d } \\
\text { Coefficients }\end{array}$} & \multirow[b]{2}{*}{$\mathrm{T}_{\text {tabel }}$} \\
\hline & & 0.52 & $\begin{array}{l}\text { Std } \\
\text { Error } \\
0.15\end{array}$ & $\begin{array}{l}\text { Bet } \\
a\end{array}$ & $\mathrm{~T}_{\text {hitung }}$ & \\
\hline & 12 & 3 & 9 & $\begin{array}{l}.5 \\
29\end{array}$ & $\begin{array}{l}.29 \\
6\end{array}$ & $\begin{array}{l}.08 \\
4\end{array}$ \\
\hline
\end{tabular}

Berdasarkan tabel 4 disposisi terhadap kemampuan pemecahan masalah matematis diperoleh nilai a (konstanta) $=16,312 \mathrm{~b}$ (koefisien regresi) $=0.523$, dengan demikian persamaan regresinya sebagai berikut : $Y=$ $16.312+0.523 X$. Diperoleh uji $t_{\text {hitung }}=3.296$ dengan signifikansi $=0.003$ dan diperoleh $\mathrm{t}_{\text {tabel }}=2.048$. berdasarkan kriteria, maka $\mathrm{t}_{\text {hitung }}$ $=3.296>2.048=\mathrm{t}_{\text {tabel. }}$. Dengan demikian ada pengaruh secara signifikan Disposisi matematis terhadap kemampuan pemecahan masalah matematis siswa.

\section{Pembahasan}

Disposisi matematis adalah suatu kebiasaan, keinginan, dan kecendrungan secara sadar dan positif terhadap matematika sehingga ketika belajar unutk menyelesaikan masalah siswa akan termotivasi dan mengerjakannya dengan sungguh-sungguh. Disposisi matematis mencakup beberapa indikator yaitu : (1) kepercayaan diri, kepercayaan diri terhadap kemampuannya. (2) keingintahuan; sering mengajukan pertanyaan, melakukan penyeldikan, antusias/semangat dalam belajar, dan banyak membaca atau mencari solusi atau sumber lain. (3) ketekunan; gigih / tekun / perhatian / kesungguhan. (4) fleksibilitas; kerjasama / berbagi pengetahuan, menghargai pendapat yang berbeda, dan berusaha mencari solusi atau strategi lain. (5) reflektif; bertindak dan berhubungan dengan matematika, menyukai / rasa senang terhadap matematika.

Disposisi matematis sangat berperan penting dalam kemampuan pemecahan masalah matematis ataupun dalam memecahkan masalah dalam kehidupan sehari-hari. Disposisi matematis merupakan salah satu faktor yang menentukan keberhasilan siswa dalam proses pembelajaran. siswa yang memiliki disposisi matematis yang baik dapat memecahkan masalah matematis dengan baik (Puspitasari, 2017).

Pada penelitian ini diperoleh bahwa disposisi matematis berpengaruh secara signifikan pada kemampuan pemecahan masalah matematis siswa SMP kelas VII. Sebelum dilakukan tes kemampuan pemecahan masalah, siswa terlebih dahulu 
diberi angket dengan sejumlah butir pertanyaan untuk mengukur disposisi siswa. Setelah angket diisi, kemudian diberi soal uraian untuk mengukur kemampuan pemecahan masalah matematis siswa. Setelah dianalisis nilai kemampuan pemecahan masalah matematis dikelompokkan berdasarkan kriteria nilai tinggi, sedang, dan rendah. Diperoleh rata-rata disposisi kelompok siswa berkemampuan tinggi lebih baik dari kelompok siswa berkemampuan sedang dan rendah.

Begitupun rata-rata kelompok siswa sedang lebih baik dari kelompok berkemampuan rendah berdasarkan hasil kemampuan pemecahan masalah. Jika kemampuan pemecahan masalah terkonstruksi dengan baik, disposisi matematis juga akan terkonstruksi dengan baik. Saat siswa memahami masalah, kepercayaan diri siswa terlatih dengan baik. Saat siswa mulai mengerjakan soal, siswa mengemukakan pendapat masing-masing sehingga kepercayaan diri siswa dan ketekunan siswa dalam menyelesaikan masalah dapat terkontruksi.

Berdasarkan hasil analisis diperoleh indikator yang paling tinggi dicapai siswa yaitu indikator kepercayaan diri dengan persentase $57.67 \%$. Kepercayaan diri siswa banyak terbangun saat siswa diminta menyelesaikan masalah yang diberikan.

Guru sebagai fasilitator memberi arahan dan memberi kebebasan kepada siswa untuk berpendapat. Kepercayaan diri siswa ditunjukkan saat siswa bertanya kepada guru apa yang tidak dimengerti, siswa menanyakan alternative penyelesaian masalah, serta mengajukan ide-ide dalam menyelesaikan masalah yang kemudian dituliskan dalam lembar pekerjaannya.
Percaya diri berarti memiliki keyakinan terhadap diri sendiri. Percaya diri merupakan suatu sikap atau perasaan yakin atas kemampuan diri sendiri sehingga orang yang bersangkutan tidak terlalu cemas dalam tindakan-tindakannya, dapat merasa bebas untuk melakukan hal-hal yang disukainya dan bertanggung jawab atas perbuatannya, hangat dan sopan dalam berinteraksi dengan orang lain, dapat menerima dan menghargai pendapat orang lain, memiliki dorongan untuk berprestasi serta dapat mengenal kelebihan dan kekurangannya (Andani, 2016).

Pencapaian indikator ketekunan pada kelas ini memiliki persentase $50.85 \%$. Meskipun tidak ditunjukkan secara prosedural dalam bentuk tulisan yang rapi, dapat dilihat ketika proses menyelesaikan masalah. Ketekunan siswa berarti bekerja keras dan bersungguh-sungguh. Tekun menjadi sikap terpuji dari seseorang sehingga tidak menutup kemungkinan jika seorang memiliki ketekunan yang tinggi hidunya akan berubah menjadi lebih baik dan maju. Tekun dalam mengerjakan matematika akan memberikan manfaat yaitu melatih cara berfikir matematis, masalah matematika akan terselesaikan tepat waktu, melatih untuk bersifat cermat, teliti dan tidak ceroboh (Khoiriyah, 2018).

Pencapaian indikator berpikir terbuka dan fleksibel pada kelas VII SMP St Yoseph Kupang memiliki persentase $43.92 \%$. Siswa masih menanam sifat ego ketika ditanya atau diminta pendapat oleh teman sekelasnya. Tentu pada proses ini perlu bimbingan dari guru, karena usia siswa yang masih pada proses remaja, sehingga memiliki rasa ego yang tinggi. Ada juga siswa mengerjakan penyelesaian masalah bergantung pada siswa yang dianggap mampu oleh teman sekelasnya. Fleksibel atau keterbukaan merupakan perwujudan dari sikap jujur, 
rendah hati, adil, mau menerima pendapat, kritik dari orang lain, dan berusaha mencari solusi atau strategi lain (Andani, 2016).

Minat dan keingintahuan pada kelas ini memperoleh persentase paling rendah yaitu $44.63 \%$ dibandingkan dengan pencapaian indikator lainnya. Siswa kebanyakan pasrah atau tetap diam dan tenang ketika mengerjakan soal yang dianggap sulit. Hal ini menunjukkan rasa keingintahuan dari siswa kurang termotivasi. Siswa lebih berminat mengerjakan soal yang mudah. Rasa ingin tahu dan daya temu dalam melakukan tugas matematika merupakan sifat positif yang dimiliki siswa dalam belajar matematika.

Setiap oang diberi rasa ingin tahu yang sangat besar terhadap sesuatu. Menciptakan rasa ingin tahu dan daya temu dalam melakukan tugas matematika bisa dengan mengarahkan siswa agar berpikir terbuka, belajar dengan hal yang menyenangkan dan berpikir dua kali misalnya mencari lebih banyak materi matematika (Khoiriyah, 2018).

Pada uji hipotesis diperoleh bahwa disposisi matematis berpengaruh secara signifikan pada kemampuan pemecahan masalah matematis siswa. Hal ini dapat dilihat dari pengelompokkan disposisi berdasarkan kemampuan pemecahan masalah matematis siswa. Siswa yang berdisposisi tinggi memiliki rata-rata 63.04 , rata-rata siswa berdisposisi sedang memiliki rata-rata 43.56 , dan rata-rata siswa berdisposisi rendah yaitu 40.51 .

Pencapaian indikator mengevaluasi pada kelas yang diteliti lebih baik setelah pencapaian indikator kepercayaan diri. Setelah siswa menyelesaikan pengerjaan masalah yang diberikan, siswa memeriksa kembali pekerjaan mereka. Mengamati kembali langkah-langkah penyelesaian masalah yang diberikan. Apakah langkahlangkah yang dikerjakan sudah sesuai dengan jawaban yang dituju. Dalam matematika siswa perlu berminat terhadap matematika, memiliki minat ditunjukkan dengan sikap keingintahuan dan daya cipta dalam aktivitas bermatematika. Selanjutnya siswa juga harus mampu melakukan monitoring dan evaluasi terhadap kinerja dirinya dalam pembelajaran matematika. Hal ini ditunjukkan dengan adanya tujuan yang ditetapkan siswa untuk dirinya sendiri (Fahrudin, 2016). Hal tersebut sesuai dengan hasil analisis data penelitian diperoleh uji $\mathrm{t}_{\text {hitung }}=3.252>2.048=\mathrm{t}_{\text {tabel }} \mathrm{l}$.

Jika disposisi dilakukan secara sadar dan terus menerus maka siswa akan mampu meningkatkan kemampuan pemecahan masalah dalam pembelajaran matematika.

$$
\text { Pembahasan bukan sekadar }
$$

menarasikan data. Urutan pembahasan selaras urutan sajian data: cocokkan hipotesis / harapan dengan data. Berikan analisis atau tafsiran. Kembangkan gagasan atau argumentasi dengan mengaitkan hasil/ teori/ pendapat/ temuan sebelumnya, a.l. dengan membandingkan dengan temuan terdahulu, adakah pertimbangan teoretis, adakah kemungkinan manfaat, dan adakah kemungkinan keterbatasan hasil. Kembangkan argumen dalam paragraf. Isi pada bagian ini lebih-kurang 35\% dari total halaman naskah.

\section{Simpulan dan Saran}

\section{Simpulan}

Berdasarkan hasil analisis data dan pembahasan dapat disimpulkan bahwa ada pengaruh yang signifikan disposisi matematis terhadap kemampuan pemecahan masalah 
matematis siswa. Hal ini dapat dilihat dari persentase pencapaian indikator disposisi dan pengelompokkan disposisi berdasarkan kemampuan pemecahan masalah matematis.

\section{Saran}

Penulis menyarankan agar disposisi siswa perlu dikembangkan dan dioptimalkan agar dapat berperan dengan baik dalam hal kemampuan pemecahan masalah matematis.

\section{Daftar Pustaka}

Abidin, Z. (2015). Intuisi Dalam Pembelajaran Matematika. Jakarta: Lentera Ilmu Cendekia.

Astriyandi, A. (2016). Kemampuan Guru Menerapkan Penilaian Autentik dalam Pembelajaran PPKN. Jurnal Bhineka Tunggal Ika.

Atullaeliyah, S. (2015). Penerapan Model Pembelajaran Kooperatif Tipe TTW (Think Talk Write) untuk meningkatkan HAsil Belajar Siswa Pada Konsep Ekosistem di Kelas VII MTS Negeri Palimanan.

Awaliyah, G. (2015). Pengaruh Kemampuan Pemecahan Masalah Terhadap Hasil Belajar Matematika Siswa Kelas V SD Se-Gugus Ki Hajar Dewantara Kecamatan Tegal Timur Kota Tegal.

Cahyono, T. (2015). Statistik Uji Normalitas. Purwekerto: Yayasan Sanitarian Banyumas.

Tatag Yuli Eko Siswono, M. P. (2018). Pembelajaran Matematika Berbasis Pengajuan dan Pemecahan Masalah. bandung: PT Remaja Rosdakarya .

Kuntjojo. (2009). Metodologi Penelitian. Kediri.

Lahinda, Y., \& Jailani. (2015). Analisis Proses Pemecahan Masalah Matematika Siswa Sekolah Menengah Pertama. Jurnal Riset Pendidikan Matematika.

Muliyatun. (2014). Analisis Keterampilan Dasar Mengajar Mahasiswa Calon Guru Kimia (Studi pada Praktik Pengalaman Lapangan Mahasiswa Tadris Kimia).
Nasution, e. Y. ( 2018). Analisis terhadap Disposisi Berpikir Kreatif Siswa Pada Pembelajaran Matematika. Jurnal Riset Pendidikan Matematika.

Nulangi, T. M. (2018, Mei 24). Retrieved maret 16, 2019, from Kupang.tribunnews.com: https://www.google.com/amp/kupang.tribunnew s.com/amp/2018/05/24/ini-alasan-nilai-ratarata-un-smp-di-propinsi-ntt-menurrun

Nurfitriyanti, M. (2017). Peningkatan Kemampuan Disposisi Matematika Melalui Pembelajaran Berbasis Aktivitas Siswa. Jurnal SAP Vol. 2 No. 1 .

Prof.Dr. H. Gunarto, M. H. (2013). Model dan Metode Pembelajaran di Sekolah.

Puspitasari, E. (2017). Pengaruh Disposisi Matematis Dan Berpikir Kritis Terhadap Kemampuan Pemecahan Masalah Matematika. Jurnal Pendidikan Dasar.

Riduwan. (2011). pengantar statistika. Bandung: Alfabeta.

Saputra, I. D. (2016). Pengaruh Persepsi Terhadap Prestasi Belajar Matematika Siswa Kelas VIII SMP/MTs SE-Kecamatan Gombong Kabupaten Kebumen Tahun Pelajaran 2015/2016.

Septa, H. W. (2013). peningkatan kemampuan pemecahan masalah dan disposisi matematis siswa dengan pembelajaran berbasis masalah (PBM).

Siswono, T. Y. (2018). Pembelajaran Matematika Berbasis Pengajuan dan Pemecahan Masalah.

suhaji, A. W. (n.d.). Pengaruh Kemampuan Dan Motivasi Terhadap Kinerja Karyawan.

Sumarmo, P. D. (2013). Berpikir dan Disposis Matematik Serta Pembelajarannyai. Bandung.

Sumarmo, P. D. (2013). Berpikir dan Disposisi Matematika Serta Pembelajarannya. Bandung.

Syaharuddin. (2016). Deskripsi Kemampuan Pemecahan Masalah Matematika Dalam Hubungannya Dengan Pemahaman Konsep Ditinjau DAri Gaya Belajar Siswa Kelas VIII SMPN 4 Binamu Kabupaten Jeneponto.

Widyasari, N., Dahlan, J. A., \& Dewanto, S. (2016). Meningkatkan Kemampuan Disposisi Matematis Siswa SMP Melalui Pendekatan Metaphorical Thinking. Jurnal Pendidikan MAtematika daan Matematika. 
Winarno, M. E. (2013). Metodologi Penelitian dalam Pendidikan Jasmani. Malang: Universitas Negeri Malang.

Zahara, K. (2018). Pengaruh Model Pembelajaran Kooperatif Tipe Think Talk Write Terhadap Kemampuan Pemecahan Masalah Matematika Siswa Kelas X SMA Negeri 2 Percut Sei Tuan. 